\title{
ANALYSIS OF THE COEFFICIENTS OF CYTOLOGICAL EXAMINATION PERFORMED AND ALTERED IN PARANÁ
}

\section{Análise dos coeficientes de exames citopatológicos realizados e alterados no Paraná}

\section{Análisis de los coeficientes de examenes citopatológicos realizados y cambios en Paraná}

Amanda Rotava Herget ${ }^{1}$, Ana Carolina Rak Bueno ${ }^{2}$, Aliny de Lima Santos ${ }^{3}$

How to cite this article:

Herget AR, Bueno ACR, Santos AL. Analysis of the coefficients of cytological examination performed and altered in Paraná. 2020 jan/dez; 12:1125-1131. DOI: http://dx.doi.org/0.9789/2175-5361.rpcfo.v12.8011.

\begin{abstract}
Objective: Analyze the behavior of the coefficients of cytological examination performed and altered in women from Paraná between 2006 and 2014. Methods: Cross-sectional study of the ecological type used data from the Cervical Cancer Information System, according to the age range of 15 to 59 years old. The ratio between the number of cervical cancer cases according to age group and women of the same age group, divided by 100,000, was calculated. Results: Were presented according to descriptive statistics, using graphs and tables. Conclusion: There was an increase in the number of examples performed in the 15-19 and 50-59 age groups, and in the age group 20-49. The altered exams increased in the studied period in the groups 15-19 and 30-49 and fell in the others. The study evidences a change in the profile of those who seek the cytological examination, with an increase in the demand by the younger, as well as altered exams in the same ones.
\end{abstract}

Descriptors: Papanicolaou Test; Mass Screening; Epidemiologic studies; Uterine Cervical Dysplasia; Primary Health Care.

\section{RESUMO}

Objetivo: Analisar o comportamento dos coeficientes de exames citopatológicos realizados e alterados em mulheres Paranaenses no período de 2006 a 2014. Método: Estudo transversal do tipo ecológico, utilizou dados do Sistema de Informação do Câncer do Colo do Útero, segundo faixa etária de 15 a 59 anos. Foi calculada a razão entre o número de casos de câncer de colo uterino, segundo a faixa etária, e mulheres paranaenses da mesma faixa etária, divididos por 100.000. Resultados: Apresentaram-se segundo estatística descritiva, utilizando gráficos e tabelas. Mostraram um aumento de exames realizados nas faixas etárias 15-19 e 50-59 anos, e quedas nas centrais, 20-49 anos. Os exames alterados aumentaram no período estudado nas faixas de 15-19 e 30-49 anos, e caíram nas demais. Conclusão: O estudo evidencia uma mudança no perfil daquelas que procuram o exame citopatológico, com aumento da busca pelas jovens, assim como de exames alterados nas mesmas.

Descritores: Exame papanicolau; Programas de rastreamento; Estudos epidemiológicos; Displasia do Colo do Útero; Atenção Primária à Saúde.

1 Medical Student, University Center of Maringá.

2 Medical Student, University Center of Maringá.

$3 \mathrm{PhD}$ in Nursing. Undergraduate professor in Medicine and Nursing at Centro Universitário de Maringá. 


\section{RESUMÉN}

Objetivo: Analizar el comportamiento de los coeficientes del examen citológico realizado y alterado en mujeres de Paraná entre 2006 y 2014. Método: Estudio transversal del tipo ecológico utilizó datos del Sistema de Información del Cáncer Cervical, de acuerdo con el rango de edad de 15 a 59 años de edad. Se calculó la relación entre el número de casos de cáncer cervical según el grupo de edad y las mujeres del mismo grupo de edad, dividido por 100.000. Resultados: Se presentaron de acuerdo con estadísticas descriptivas, usando gráficos y tablas. Hubo un aumento en el número de exámenes realizados en los grupos de 15-19 y 50-59 años, y en los grupos de edad de 20-49. Los exámenes alterados aumentaron en el período estudiado en los grupos 15-19 y 30-49 años y disminuyeron en los otros. Conclusión: El estudio evidencia un cambio en el perfil de quienes buscan el examen citológico, con un aumento en la demanda por parte de los más jóvenes, así como también exámenes alterados en los mismos.

Descriptores: Prueba de Papanicolaou; Tamizaje Massivo; Estudios epidemiológicos; Displasia del Cuello del Útero; Atención Primaria de Salud.

\section{INTRODUCTION}

Cancer poses a major public health problem worldwide. According to the World Health Organization (WHO), in 2012, there were 14.1 million new cases and approximately 8.2 million deaths from cancer in the world ${ }^{1}$. Behind diseases of the circulatory system and external causes, cancer is the third largest cause of death in Brazil. In addition, prevention and early diagnosis are the best way to reduce this index ${ }^{2}$.

With regard to cancers affecting the female population, the National Cancer Institute (INCA) highlights cervical cancer as the fourth most frequent in developed countries, with approximately 529,000 cases and 275,000 deaths per year worldwide, in addition to more than $85 \%$ of the global burden of the disease being distributed in low and middle income countries ${ }^{3}$. As the etiological agent of this disease, the Human Papillomavirus (HPV) is found in almost $100 \%$ of cases of cervical cancer, however, associated with the progress of pre-invasive lesions caused by it, there are other risk factors associated with this evolution, such as smoking, multiple sexual partners, multiparity and early sexual initiation ${ }^{4}$.

HPV infection is common in young adults of both sexes, but the man is recognized as a great propagator of this virus among women ${ }^{5}$. HPV presents more than 100 types of viruses, however, those considered oncogenic, are found in $70 \%$ of cases of cervical cancer, while non-oncogenic ones, are found in $90 \%$ of pre-neoplastic lesions ${ }^{6}$. In spite of this, it is known that there are approximately 291 million women infected by the Human Papillomavirus, and $32 \%$ of them by types 16,18 , or both, considered oncogenic ${ }^{6}$.

In Brazil, cervical cancer is the third most frequent cancer, its incidence and mortality being high, occurring between 5 to 6 deaths every 100,000 women per year. In 2014 alone, the increase of new cases was 15,590 with approximately 5000 deaths $^{3}$, for the year 2016 the estimate of new cases was
16,340 with an incidence of 15.85 cases for every 100,000 women. The northern region of the country is the one with the highest incidence of this type of cancer, followed by the Midwest and Northeast regions ${ }^{7}$.

The Papanicolau Test (PAP Test) is currently the main strategy for detecting pre-neoplastic and neoplastic lesions and the HPV virus, consequently, for diagnosing cervical cancer ${ }^{2}$. It is carried out annually, but from negative results for two consecutive years, it is carried out every three years. This examination is considered efficient, low cost and easy to access, being carried out free of charge in Basic Health Units $^{8}$. The BHUs have the function of promoting health through the dissemination of information to the population and preventing conditions of illness through actions such as the conduct of this examination. However, this information is not always passed on to a large part of the female population, since the latter does not have sufficient prior knowledge of the importance of this examination ${ }^{8}$.

A greater focus on primary attention is of great interest in order to change the way information is passed on and increase the dialogical approach between health teams and the female population. It is necessary that health professionals develop a greater perception about the previous knowledge of this population, in order to clarify doubts about the examination and consequent development of cancer, aiming at the reduction of morbimortality rates and increase of the prevention and promotion of women's health ${ }^{8}$.

In addition to these factors, an increase in the search for women for appropriate treatment is important, when abnormal results are present, in addition to the capture of those in groups considered to be at risk, or age of greatest incidence, in order to show them that the PAP Test is a preventive exam, and not just a diagnostic instrument ${ }^{9}$.

The relationship between low rates of mortality from cervical cancer, the quality of screening and outpatient health services, as can be seen when comparing developing countries such as Brazil and developed countries, is notorious. The extent to which the rates of morbidity and mortality from cervical cancer are low in the countries that are developed, they show themselves stabilized or even increasing in Brazil. This relationship shows that the diagnosis of the disease is intrinsically associated with the quality of the health services, in relation to the prevention of aggravation by means of tracking actions ${ }^{9}$.

In spite of this, there is still a low adhesion to this examination in Brazil, not only due to lack of information, disorganization of service regarding active search and failure in prevention and/or early detection campaigns, but also due to the presence of factors such as beliefs, attitudes, feelings of shame, pain, discomfort ${ }^{10}$.

Although this is a very relevant topic, it is noticed that it has not been investigated insistently in the national literature, especially regarding the investigation of the behavior of cytopathological coefficients performed and altered in specific regions of the country. Therefore, in view of the 
relevance of the topic, the present study aimed to analyze the behavior of the coefficients of cytopathological examinations performed and altered in women resident in Paraná in the period between 2006 and 2014.

\section{METHODS}

It is a study of descriptive, transversal, ecological analysis, referring to the behavior of cervical cancer coefficients in the state of Paraná during the years 2006 and 2014. The state is officially composed of 399 municipalities with a total of 11,163,018 inhabitants. In 2016, it ranked 6th among the federal units with the highest population and best life expectancy (74.9 years), 4 th in infant mortality ( $12.0 \%$ birth), and 5 th in HDI $\left(0.749\right.$-high) ${ }^{11}$.

The data referring to cervical cancer coefficients analyzed were collected in the database of DATASUS (Data Processing Department of SUS), according to the International Classification of diseases, 10th revision - CID-10 (WHO, 2008). The age categories used were similar to those presented by DATASUS: “15-19”, "20-29”, “30-39, “40-49” and "50-59."

The information was obtained in the database of SISCOLO 4.0 (Cervical Cancer Information System), version 4.0 or higher refers to data after 2005 , made available by the SUS Computer Department (DATASUS)/Ministry of Health in the section "Health Information", in the item information "Epidemiological and Morbidity", in the options corresponding to "Cervical and breast cancer (SISCOLO/ SISMAMA)", as use of the values from the years 2006 to 2014, and the data of the population estimates were collected from the Brazilian Institute of Geography and Statistics (IBGE).

The coefficients of both the incidence and prevalence of cancer of the cervix of the uterus was calculated by taking the ratio of the number of new cases that have occurred in the state of Paraná, in the period of 2006-2014, the number of people at risk of developing the disease during the same period, and multiplying this quotient by 100,000 , and the ratio of the number of people with the disease in the Population at Risk (PR), in the same year, and multiplying this quotient by 100,000, respectively. The coefficients were standardized using as standard Population A of the state of Paraná for each year studied, according to the series. Thus, the trend analysis was given by means of standardized incidence coefficients and prevalence of cervical neoplasia, according to federal unit and year. It should be noted that the data collection took place in the period of 2006 and 2014.

For tabulation and grouping of data, calculation and analysis of hospitalization rates, Microsoft Office Excel software (version 2013) was used, being the same used for analysis and graphing.

The study, according to Resolution 466 of 12 December 2012 of the National Health Council, did not present ethical implications because it used secondary and grouped data, in which no information was provided that could identify individuals. This way, dispensation was requested from the Ethics Committee of the University Center of Maringá UNICESUMAR (PPA: 5 7426016.6.0000.5539).

\section{RESULTS}

In the course of the study, in a general way, one can see a certain linearity in the cytological exam coefficients done and altered in the state of Paraná, in conjunction with an increase in the number of tests performed and altered in the age-group of 15-19 years of age, while the next track (2029 years old), it is clear that, although the number of tests performed is twice the previous age group, the number of altered tests is not far from it. (Table 1).

Although there was a drop in almost all age groups, except the age group of 15 to 19; the age group of 20 to 29 was the one that presented the highest number of exams with altered results, followed by that of 30 to 39 years old. In addition, it was observed that the coefficients of exams changed in the age groups 20 to 29 and 50 to 59, and all the others showed an increase (Table 1). The reduced coefficients in 2014 are highlighted, pointing the lack of information about these exams, and therefore disregarded in the analysis of the percentage variation.

Table 1 - Distribution of coefficients* of cytopathological examinations performed and altered in women resident in Paraná, according to age and year of notification, in the period of 2006 to 2014. Maringá, Paraná, 2016.

\begin{tabular}{|c|c|c|c|c|c|c|c|c|c|c|}
\hline \multirow{2}{*}{ Year } & \multicolumn{2}{|c|}{$15-19$ years old } & \multicolumn{2}{|c|}{ 20-29 years old } & \multicolumn{2}{|c|}{ 30-39 years old } & \multicolumn{2}{|c|}{ 40-49 years old } & \multicolumn{2}{|c|}{ 50-59 years old } \\
\hline & Performed & Altered & Performed & Altered & Performed & Altered & Performed & Altered & Performed & Altered \\
\hline 2006 & 7001,3 & 256,9 & 15600 & 396,9 & 17511,9 & 333,6 & 19850,3 & 318,2 & 18466 & 233,6 \\
\hline 2007 & 9156,6 & 285,8 & 17927,7 & 410,6 & 21312,9 & 372,9 & 21157,4 & 300,2 & 19204,8 & 231 \\
\hline 2008 & 8013,1 & 273,3 & 15433,3 & 385,1 & 18633,5 & 360,7 & 18734,8 & 303,2 & 17285,4 & 218,1 \\
\hline 2009 & 9110,9 & 330,4 & 16944 & 463,9 & 20398,7 & 409 & 21212,1 & 348,1 & 20019,6 & 248,2 \\
\hline 2010 & 8417 & 336,9 & 15770,4 & 449,5 & 18615,7 & 418,6 & 20114,3 & 368,1 & 19594,2 & 263,3 \\
\hline 2011 & 8877,5 & 379,6 & 16003,3 & 501,3 & 18984,5 & 463 & 21217,4 & 409,5 & 21048,2 & 307,4 \\
\hline 2012 & 8194,5 & 324,8 & 14170,2 & 446,4 & 17364,6 & 436,7 & 19889,3 & 380,4 & 20093,3 & 271,5 \\
\hline 2013 & 8578,5 & 300,4 & 13665 & 365,7 & 16659,8 & 381 & 19656,3 & 330,6 & 19397,3 & 233,5 \\
\hline 2014 & 809 & 29,7 & 1207,7 & 33,5 & 1477,8 & 33,4 & 1768,5 & 27,6 & 1740,8 & 20,3 \\
\hline Var.\%** & 22,5 & 16,9 & $-12,4$ & $-7,8$ & $-4,8$ & 14,2 & $-0,9$ & 3,9 & 5,0 & $-0,04$ \\
\hline Total & 68158,4 & 2517,8 & 126721,6 & 3452,9 & 150959,3 & 3209 & 163600,4 & 2785,9 & 156849,6 & 2027 \\
\hline
\end{tabular}

* Examinations per 100,000 inhabitants ** Percentage change from 2006 to 2013 
In Figure 1, a direct relationship was observed between the examinations performed and the age of women where, the higher the age group, the higher the number of exams. On the other hand, there is an inverse relationship between age and changes in examinations, because the further the age group, the lower the proportion of examinations with altered results. This highlights the prevalence of altered results in younger women (Figure 1).

There is also a peak in the year 2007 for the examinations carried out in almost all age groups studied (Figure 1).

Figure 1 - Coefficients of cytopathological examinations performed and altered in women residing in Paraná, second age group, from 2006 to 2014. Maringá, Paraná, Brazil, 2016.
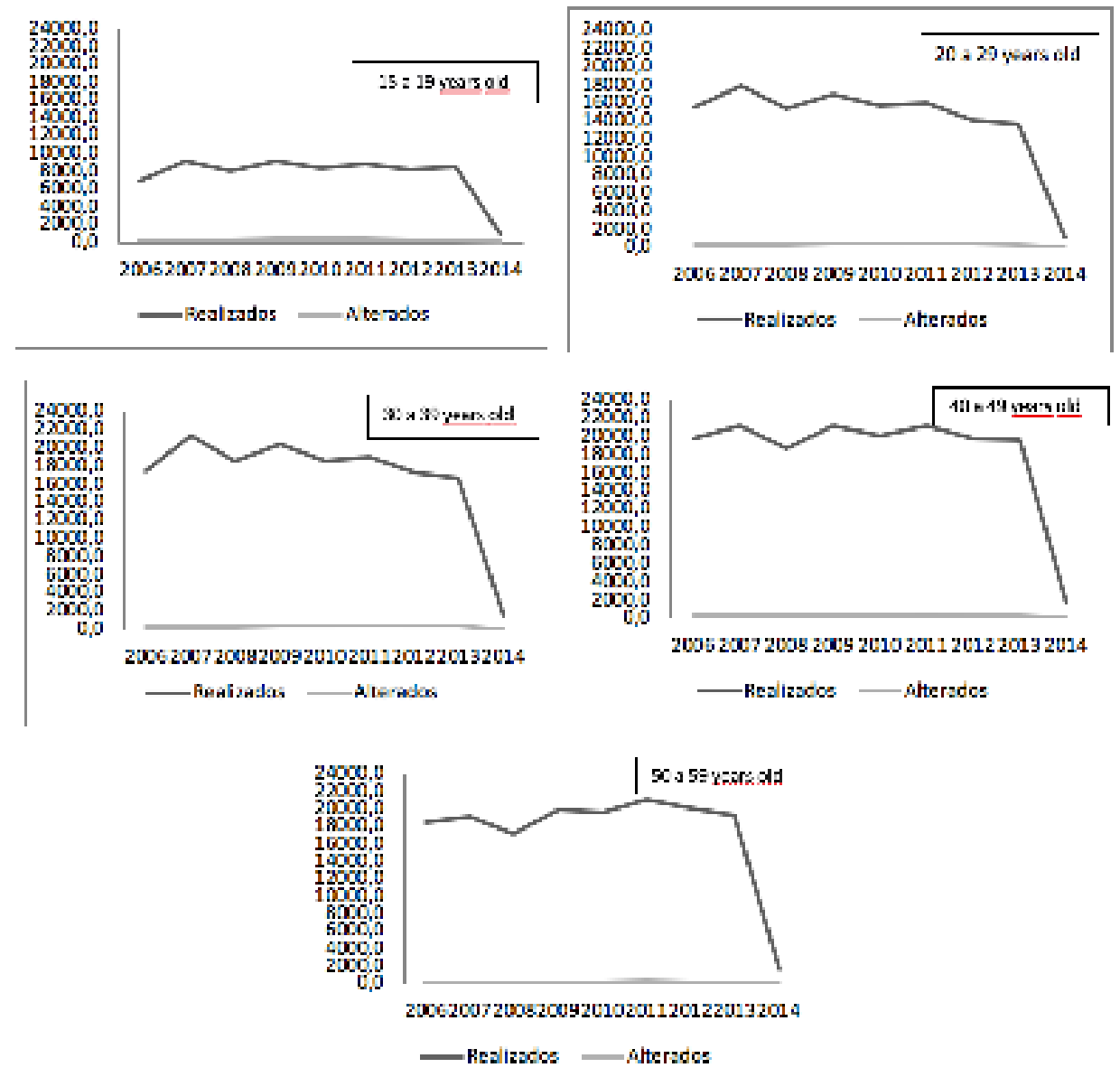

\section{DISCUSSION}

In the results found, considering the percentage variation found between the first and last year of study, the coefficients of cytopathological examinations performed in women resident in Paraná between the years 2006 and 2014 , showed that there was an increase in the coefficients of examinations performed in the ages 15 to 19 and 50 to 59 , and a decrease in the central age group, from 20 to 49. In turn, the altered exams showed growth in the 15 to 19 and 30 to 49 age groups, falling in the 20 to 29 age group, while they remained practically stable in the 50 to 59 age group. Nevertheless, it was found that with advancing age, the coefficients of examinations performed grew progressively until the age of 49 , with a drop, comparatively, in the final age group (50 to 59 years).

In turn, the altered examinations, with the total value over the years, were predominant among women from 20 to 39 years old, suffering reduction in those from age 50 .
It also draws attention to the high rates of altered examinations verified in the 15 and 19 age group, similar even to those presented in the following age groups, considered at risk by the Ministry of Health/INCA ${ }^{12}$.

The increase in examinations carried out in the age range 15 to 19 years old is not an expected situation. It is known that the disease has a slow development, and the evidence shows that cervical changes in this age usually evolve with spontaneous remission $^{13}$. For these reasons, the consensus on the periodicity and age group in the cervical cancer prevention exam determines that women up to 20 years old are not priority age group in the screening of cervical cancer ${ }^{14}$.

However, a study carried out in Panama presented 28 cases of dysplasia and 5 cases of cancer in girls aged 15-1915. Another study, this time carried out in a Guarani tribe in Argentina, showed an infection rate for HPV virus reaching $64 \%$, being the average age of $15^{16}$. Although this is not the usual behavior of the disease, these studies demonstrate 
the importance of a greater breadth not only of PAP Tests in younger women, but also of public policies to raise awareness of them. The need for greater knowledge about the cytopathological examination is corroborated by qualitative study carried out in Minas Gerais, in which the patients were questioned about the first collection of the preventive. In this, it was observed that many did not know the true purpose of the procedure, and they also reported shame and discomfort as main feelings in front of the examination ${ }^{16}$.

Many women still consider the PAP Test as an invasive procedure, which generates fear, anxiety, revulsion to the realization and prolonged delays in the search for the health service. This reflects the need for greater training of the professional team that performs the procedure, as well as an ethical and respectful posture with the patient, in order to preserve their privacy and give free choice about the treatment or procedure ${ }^{17}$. The way the professional conducts the consultation and the relationship of care established with the patient, reflects in the greater adherence to the examination and search of the health service, since the feelings of shame and fear minimized by the professional during the consultation leads to a greater demand of the patient to the Basic Health Units ${ }^{18}$.

The increase in the number of altered exams among girls aged 15 to 19 is supported by this premise of a lack of information, both due to low education and low socioeconomic status. Adolescents who are starting sexual activity earlier, and because of this knowledge gap end up not practicing safe sex, with a condom, capable of protecting against sexually transmitted diseases, which is the main form of contact with the HPV virus, which causes the disease ${ }^{19}$.

Promoting actions in favor of knowledge and adherence to cytopathological examination generates a direct benefit in screening and contiguity in the early detection of potentially malignant lesions. Thus, it is possible to increase the survival of many women, since screening is able to reduce the incidence of cervical carcinoma, even if performed 10 years apart, for two out of three women, in addition to exerting a protective effect after a negative test, in $91 \%$ of women aged 35-64 who collect every 3 years ${ }^{20}$.

Although it has not yet reached the goal proposed by the Ministry of Health and the WHO, $80 \%$ of the coverage of the at-risk population by the PAP Test, in Brazil, there was a range of $79.3 \%$ in 2008 , and $73,8 \%$ in 2013 , and it is better, for example, that in countries such as Argentina, the United Kingdom and Canada, all of which had lower percentage ${ }^{21}$.

Thus, in the result, the increase in the performance of cytopathological examinations in the extreme age groups, with a peak in 2007, is probably a reflection of the National Policy of Oncological Attention (PNAO). This policy placed as an essential component, foreseen in the state and municipal health plans, the control of cervical and breast cancers and the Pact for Health (2006), which reaffirmed the importance of early detection. The fall then can represent both a decrease in incentive and propaganda, "cooling off" discussion and politics, and a failure in the system's food supply.

When observing Table 1, we see that the record of examinations performed in all periods and age groups analyzed is the year 2011. It is supposed to be due to the fact that in this year, the Ministry of Health had extended the age range of tracking to 25 to 64 , resulting in the search for gynecological care in the SUS by women who previously did not seek the exam.

Women aged 20 to 49 are placed in a range of risk for cervical cancer. This is due to the fact that many of them are afraid of the PAP Test, in addition to other aspects mentioned above, also for fear of presenting positive results for the disease. The lack of adherence to the preventive examination comes from models and standards of recognition according to the family, culture, or even by the difficulty of carrying out the examination because living in rural areas or places difficult to access to health services ${ }^{22}$.

It draws attention in the results the fact that the prevalence of tests with altered results occurred in the age group of 20-29, since due to the slow evolution of cervical cancer, the WHO indicates that the highest incidence range is 30-39, reaching peak in the fifth and sixth decades of life $\mathrm{e}^{23}$.

Nevertheless, it has been observed that, although there has been an increase in examinations in women aged 50 to 59 , this is still discreet. This finding corroborates the results of other studies, which show that women aged 50 to 59 have less knowledge about the purpose of the PAP Test and perform it less frequently ${ }^{23}$. This aspect is further reinforced by observing that some older women recognize the examination only as curative, relating it to Sexually Transmitted Infections, and not to a preventive procedure of cancer ${ }^{24}$.

Care for older women has aroused the interest of health professionals, and all efforts aim to increase the possibility of a more autonomous life by encouraging self-care. There is a sense of making it safer and healthier and free from preventable diseases, because the detection of diseases by early diagnosis may prolong the survival time ${ }^{25}$.

It is understandable that older women have been less exposed to information related to the prevention of cervical cancer. The lack of knowledge may also be related to the lack of communication between the health care professional and women. The educational actions should seek the participation and joint questioning of health professionals and women on the different aspects related to prevention, to education, to diseases and control actions, seeking to sensitize the latter to adopt attitudes and behaviors compatible or befitting with a healthier life ${ }^{24}$.

The present study showed that at the extremes of age rates the adhesion has had a progressive growth, as well as awareness about the importance of cytopathological examination in early diagnosis and therefore prevention for malignancies. Although advances in primary attention have reduced mortality from cervical cancer in Brazil, it is still a challenge to be overcome, since it is linked to information 
and various social determinants. Thus, when comparing the numbers of examinations performed with the number of women of childbearing age residing in Paraná, those that have regular primary attention, are still in the minority.

\section{CONCLUSION}

The intervention aimed at promoting health and preventing injury in the younger and older age groups has been shown to be important due to the increase of altered cytopathological examinations, demonstrated numerically by the present study. This is due to the fact that for a large part of the female population, the information regarding the examination and its significance is still insufficient. This proves the need for promotional and preventive health measures.

Among the limitations of the study are the lack of data in the information system, as it is possible to observe in the results, the presence of a sharp drop in the exams carried out and changed in the year 2014. Another limitation in findings may be due to the increase in the number of Basic Health Units, expanding primary attention, which causes the number of exams to increase. On the other hand, the article brings the insipidity of other works that talk about this topic, especially in the state of Paraná. The study shows a panorama of the last nine years of the examinations performed and altered, highlighting the size of the altered exams, mainly in the public of younger girls and women in the middle age group.

Therefore, the study shows the importance of developing actions aimed at primary care and the active search in order to improve the results of the preventive exam coefficients, thus contributing in the social field and passing on relevant information that can reduce the incidence and prevalence of the disease, as well as passing on the importance of adhering to the test and then reducing death rates.

\section{REFERENCES}

1. Ferreira IB, Marinho EC, Custódio IDD, Gontijo CA, Paiva CE Crispim CA. Consumo alimentar e estado nutricional de mulheres em quimioterapia. Ciênc. saúde coletiva [Internet]. 2016 July [cited 2018 Aug 08] ; 21( 7 ): 2209-2218. Available from: http://dx.doi. org/10.1590/1413-81232015217.05412015

2. Boing AF, Vargas SAL, Boing AC. A carga das neoplasias no Brasil mortalidade e morbidade hospitalar entre 2002-2004. Rev. Assoc. Med. Bras. [Internet]. 2007 Aug [cited 2018 Aug 08] ; 53( 4 ): 317-322. Available from: http://dx.doi.org/10.1590/S0104-42302007000400016

3. Barbosa IR, Souza DLB, Bernal MM, Costa ICC. Desigualdades regionais na mortalidade por câncer de colo de útero no Brasil tendências e projeções até o ano 2030. Ciênc. saúde coletiva [Internet] 2016 Jan [citado 2018 Ago 08] ; 21( 1 ): 253-262. Disponível em: http://www.scielo.br/scielo.php?script=sci_arttext\&pid=S141381232016000100253\&lng=pt.

4. Pimentel AV, Panobianco MS, Almeida AM, Oliveira ISB. Percepção da vulnerabilidade entre mulheres com diagnóstico avançado do câncer do colo do útero. Texto contexto - enferm. [Internet]. 2011 June [cited 2018 Aug 08] ; 20 ( 2 ): 255-262. Available from: http://dx.doi. org/10.1590/S0104-07072011000200006.
5. Reis AAS, Monteiro CD, Paula LB, Santos RS, Saddi VA, Cruz AD. Papilomavírus humano e saúde pública: prevenção ao carcinoma de cérvice uterina. Ciênc. saúde coletiva [Internet]. 2010 June [cited 2018 Aug 08] ; 15( Suppl 1 ): 1055-1060. Available from: http://dx.doi. org/10.1590/S1413-81232010000700012.

6. Instituto Nacional do Câncer. INCA. Rio de Janeiro, 2016. Disponível em: http://ww.inca.gov.br/. Acesso em: 20 Nov 2016.

7. Renna Junior NL, Silva GA. Tendências temporais e fatores associados ao diagnóstico em estágio avançado de câncer do colo uterino: análise dos dados dos registros hospitalares de câncer no Brasil, 20002012. Epidemiol. Serv. Saúde [Internet]. 2018 [cited 2018 Aug 08] 27( 2 ): e2017285. Available from: EpubMay07, 2018. http://dx.doi. org/10.5123/s1679-49742018000200003.

8. Souza KR, Paixão GPN, Almeida ES, Souza AR, Lirio JGS, Campos LM EDUCAÇÃO POPULAR COMO INSTRUMENTO PARTICIPATIVO PARAA PREVENÇÃO DO CÂNCER GINECOLÓGICO: PERCEPÇÃO DE MULHERES. Rev Cuid [Internet]. 2015 Jan [cited 2018 Aug 08] ; 6( 1 ): 492-499. Available from: http://dx.doi. org/10.15649/cuidarte.v6i1.129.

9. Davim RMB, Torres GV, Silva RAR, Silva ADR. Conhecimento de mulheres de uma Unidade Básica de Saúde da cidade de Natal/RN sobre o exame de Papanicolau. Rev. esc. enferm. USP [Internet]. 2005 Sep [cited 2018 Aug 08] ; 39( 3 ): 296-302. Available from: http:// dx.doi.org/10.1590/S0080-62342005000300007.

10. Silva MAS, Teixeira EMB, Ferrari RAP, Cestari MEW, Cardelli AAM. Fatores relacionados a não adesão à realização do exame de Papanicolau. Rev. Rene [Internet] 2015 jul-ago [cited 2018 Aug 07].

11. Brasil. Instituto Brasileiro de Geografia e Estatística [homepage na internet]. Estatísticas por cidade e estado - Paraná [acesso em 30 out 2016]. Disponível em: http:www.ibge.gov.br

12. Diretrizes brasileiras para o rastreamento do câncer do colo do útero / Instituto Nacional de Câncer. Coordenação Geral de Ações Estratégicas. Divisão de Apoio à Rede de Atenção Oncológica. - Rio de Janeiro: INCA, 2011 - http://bvsms.saude.gov.br/bvs/publicacoes/ inca/rastreamento_cancer_colo_utero.pdf

13. Fletcher AH, Wilkinson EJ, Knapik JA. Oncogenic human papillomavirus testing in an adolescent population with atypical squamous cells of undetermined significance. J Low Genit Tract Dis. 2009; 13(1):28-32.

14. Instituto Nacional de Câncer (Brasil). Consenso - Periodicidade e Faixa Etária no Exame de Prevenção do Câncer Cérvico-Uterino. Rio de Janeiro. ProOnco/INCA. 1988

15. Garrido JL. 30 years of preventive studies of uterine cervical cancer 1982-2012. Eur J Gynaecol Oncol. 2015;36:252-4

16. Trindade GB, Manenti SA, Simões PW, Madeira K. Avaliação do rastreamento do câncer do colo do útero e sua periodicidade em um município de Santa Catarina.Medicina (Ribeirao Preto, Online), Ribeirão Preto, v. 50, n. 1, p. 1-10, feb. 2017. ISSN 2176-7262. Disponível em: <http://www.revistas.usp.br/rmrp/article/view/134993>.

17. Eduardo KGT, Américo CF, Ferreira ERM, Pinheiro AKB, Ximenes LB. Preparação da mulher para a realização do exame de Papanicolau na perspectiva da qualidade. Acta paul. enferm. [Internet]. $2007 \mathrm{Mar}$ [cited 2018 Aug 08] ; 20 ( 1 ): 44-48. Available from: http://www.scielo. $\mathrm{br} /$ scielo.php?script=sci_arttext\&pid=S0103-

18. Jorge RJB, Diógenes MAR, Mendonça FAC, Sampaio LRL, Jorge Júnior R. Exame Papanicolaou: sentimentos relatados por profissionais de enfermagem ao se submeterem a esse exame. Ciênc. saúde coletiva [Internet]. 2011 May [cited 2018 Aug 08] ; 16( 5 ): 2443-2451. Available from: http://dx.doi.org/10.1590/S1413-81232011000500013.

19. Cruz DE. Jardim DP. Adolescência e Papanicolau: conhecimento e prática. Adolesc Saude. 2013;10 (Supl. 1):34-42.

20. Ministério da Saúde, Instituto Nacional do Câncer. Periodicidade de realização do exame preventivo do câncer do colo do útero: normas e recomendações do INCA. Rev Bras Cancerol 2002;48(1):13-5.

21. Brasil. Ministério da Saúde. Exame Preventivo do câncer de colo uterino (Papanicolau). Biblioteca virtual de Saúde. Jul 2011. Acessado em: 20 Nov 2016. Disponível em: http://bvsms.saude.gov.br/bvs/ dicas/237_papanicolau.html. 
22. Ferreira MLSM. Motivos que influenciam a não-realização do exame de papanicolau segundo a percepção de mulheres. Esc. Anna Nery [Internet]. 2009 June [cited 2018 Aug 08] ; 13( 2 ): 378-384. Available from: http://dx.doi.org/10.1590/S1414-81452009000200020.

23. Olhê L, Oliveira RC, Campanelli RF, Nogueira LDP. Revista Fafibe Online - ano VI - no 6 - nov. 2013 [Internet]. Papanicolau na terceira idade: um desafio para a enfermagem. 2013.Available from: unifafibe. com.br/revistafafibeonline

24. Maeda TC, Alves AP, Silva SR. Conhecimento de mulheres idosas sobre o exame Papanicolau. Cienc Cuid Saude 2012 Abr/Jun; 11(2):360-367.

25. Barreto AMMA, Oliveira FMC, Gomes MQC. Intervenção educativa em saúde para idosas à cerca do exame Papanicolau. Revista Online de Pesquisa: Cuidado é Fundamental [Internet]. 2018 [cited 2018 Aug 06].

Received in: 14/08/2018

Required revisions: 19/12/2018

Approved in: 15/02/2019

Publicado em: 24/08/2020

\section{Corresponding author}

Aliny de Lima Santos

Address: Avenida Guedner, 1610, Jardim Aclimação

Maringá/PR, Brazil

Zip code: $87050-900$

Email address: aliny.santos@unicesumar.edu.br 